\title{
ARABIC ASSIMILATIONS USED IN FITRAT'S JOURNALISTIC WORKS
}

\section{Sharifa Iskandarova}

Professor Fergana State University, Uzbekistan

Sayyora Mirzatillaeva

Master Student Fergana State University, Uzbekistan

\section{ABSTRACT}

The article examines the expansion and narrowing of meaning in Arabic assimilation lexemes, Fitrat's publicist works.

KEYWORDS: - Assimilations, lexical structure of language, pure language, foreign language, original meaning, semantic structure, word acquisition, expansion of meaning, narrowing of meaning, new meaning.

\section{INTRODUCTION}

Assimilation has a special place in the vocabulary replenishment of any language. According to linguists, from one language to another, first of all, a term - that is, words belonging to the category of horses - is acquired. This, of course, does not mean that words from other categories, auxiliary words, are not mastered [1,22].

"It should be noted that there is no pure language among such a large number of languages on earth. There has always been a certain amount of words going from one language to another" [2,152].

Arabic dialects play an important role in the Uzbek language dictionary. Cultural, scientific, socio-political and trade relations between nations are also reflected in their languages. It is known that in the Middle Ages, Arabic was popular in the east, and Greek and Latin in the west as the language of science. A certain part of the Uzbek lexicon also consists of Arabic words. The Arabic language had a strong influence not only on the Uzbek language, but also on the language of all peoples who converted to Islam" $[3,15]$.

\section{THE MAIN FINDINGS AND RESULTS}

We know that a certain part of the Uzbek lexicon consists of words borrowed from Arabic. Words related to science and education were mostly learned from Arabic. There are also words related to other areas. In the process of assimilation of Arabic words into our language, the original and semantic correspondence in the meaning of words was preserved some of them were used in our language in a completely 
CURRENT RESEARCH JOURNAL OF PHILOLOGICAL SCIENCES 2(6): 88-92,

May 2021 DOI: https://doi.org/10.37547/philological-crjps-02-06-18

ISSN 2767-3758

(C)2021 Master Journals

\section{Crossref do) 8 Google}

Accepted25thJune, 2021 \& Published 30thJune, 2021

different sense, as well as in them there were phenomena of expansion and contraction. Some polysemous words began to be used as synonyms.

If these features are observed in the example of Abdurauf Fitrat's journalistic articles, the above idea can be proved. For example, in creative works we refer to the lexical meaning of the word hijran:

Hijran - separation, loss,

Hijran [ هجران ] - to abandon [4].

We know that the word hijran belongs to the category of nouns and is often used in the artistic style in the sense of separation. In Arabic, however, this lexeme is used as a word belonging to a group of verbs, and is used to express the meanings of abandonment, abandonment. Below we can see examples of words that have undergone changes in semantic structure during the assimilation process as above.

For example, the word muhtoj - 1) there was a need for something.

Poor, destitute, needy $[6,666]$.

Muhtoj [محتاج] - to oppose, to resist [4] used in the sense that. The word "Muhtoj" is considered to have been borrowed from the Arabic lexicon, and in the process of assimilation, the meaning of the word has changed, the meaning of the word has narrowed. In Arabic, the word Muhtoj is used to mean to oppose, resist and protest. This word belongs to the group of adjectives derived from the verb "Ihtaja'.

Qavm - 1) An association of people descended from one generation, connected by mutual kinship; tribe, province, tribe.

2) People who always pray in a mosque and each of them. Qavm [1 - [قوم] people, nation 2) people.

The same situation can be seen in the word of the people quoted above. This word is used in the lexicon of the Uzbek language in the form of tribe-relatives in relation to persons related to each other. In Arabic, the word "Qavm" is used primarily to refer to an entire people and nation.

Haram - 1) A place designated as sacred, where entry is prohibited. 2) The part of the yard reserved for women.

Haram [ 1 - - حرم]) Depression, impotence in old age, ignorance 2) pyramid.

The word haram was originally derived from the word haram and was used in the sense of forbidden. The meaning of this word has also narrowed in the process of learning the Uzbek language. Basically, this word is used in our lexicon to describe the khan's mahrams, that is, a separate courtyard reserved for his wives. In Arabic, however, the word is used in a number of senses: Depression, weakness in old age, lethargy; pyramid.

Xuruj - 1) sudden attack, attack, 2) climb, intensify 3) exacerbation of the disease 4) indulge in something negative, $[8,427]$.

Xuruj [ 1 - خروج] Exit, introduction, destruction, debut 2) Ornaments, decorations, make-up, drums, ornaments 3) Not to talk, not to listen, not to obey. Below we continue this series of lexemes on the example of Fitrat's journalistic works. For example:

Vakillar ko'bchiligi hammadan oldinroq eski qit'aning yerlarini tuzatishga qaror bersa, chora yo'q, shu qilinur

If the majority of the deputies decide to settle the lands of the old continent first of all, there is no remedy, it will be done.

Qaror - 1) A job, a firm opinion on an issue, a stop. 2) Stop, verdict of the official organization.

3) Peace, tranquility; rest, relaxation.

Qaror [ 1 - [قرار] Accommodation, location 2) tub, bottom, depth 3) Naqarot.

The explanatory dictionary of the Uzbek language contains the above-mentioned 
CURRENT RESEARCH JOURNAL OF PHILOLOGICAL SCIENCES 2(6): 88-92,

May 2021 DOI: https://doi.org/10.37547/philological-crjps-02-06-18

ISSN 2767-3758

(C)2021 Master Journals

Crossref dof 81 Google

Accepted25thJune, 2021 \& Published 30thJune, 2021

meanings of the word Qaror, and these meanings are actively used in our speech. This word also retains some of its meaning in the process of assimilation into our language, in our language the word decision is used in reference to a firm opinion, a conclusion, the conclusion of an official organization, peace and tranquility. In the example given, the word has been used to denote an action, a firm opinion on a matter. In Arabic, however, the word is used in conjunction with the meanings we have enumerated to denote accommodation, location, as well as to denote the bottom, bottom of something, and in relation to depth.

Bu kun German va Turk davlatlarining birinchi dushmanlari anglizdir.

To this day, the first enemies of the German and Turkish states are the British

State - 1) An independent country with a system of authorities and political organizations that protects the socio-political rights of its citizens, breaking the resistance of opposing forces.

2) Wealth, property. 3) Spiritual wealth: happiness, luck. Davlat [ - مولت 1) State, empire. 2) Dominance, domination. 3) Sulola, dynasty 4) Infidelity, chaos, variability.

In the process of assimilation, the following changes in the semantics of this word are considered to have taken place. In the example, the word state means an independent country with a system of authorities and political organizations that protects the socio-political rights of its citizens, breaking the resistance of opposing forces. In Arabic, however, the word is used to denote a dynasty as well as infidelity in addition to those mentioned. In the Uzbek language, the word state is used in its own sense only to denote supreme power, and in a figurative sense to denote happiness and wealth.

$\mathrm{O}^{\prime} \mathrm{z}$ xalqlarini yana boshqalarning oyoqlari ostinda qo'ymoqchi bo'lmag'an musulmonlar!Saylov kuni g'ofil qolmanglar.

Muslims who do not want to put their people under the feet of others again! Do not be ignorant on election day.

Xalq - 1) People 2) Different forms of historical unity; tribe, ethnicity, nation 3) Population of a particular place 4) People gathered in one place; crowd 5) Comes with words denoting a profession, occupation, category or gender and refers to a group of people belonging to the same profession, occupation, category or gender .

Xalq [1 - خلق] to create; 2) people; 3) creature, animal; 4) stature and body

The word Xalq is actively used in our language in various senses. In fact, the content of this word is the same in Arabic and Uzbek. The word Xalq has two different integral semantics in both languages. Let's compare the semantic structure of the word folk in Uzbek and Arabic languages: 
CURRENT RESEARCH JOURNAL OF PHILOLOGICAL SCIENCES 2(6): 88-92,

May 2021 DOI: https://doi.org/10.37547/philological-crjps-02-06-18

ISSN 2767-3758

(C)2021 Master Journals

Crossref dof 81 Google

Accepted25thJune, 2021 \& Published 30thJune, 2021

\begin{tabular}{|l|c|}
\hline \multicolumn{1}{|c|}{ In Arabic } & In the Uzbek language \\
\hline To create, & Tribe, nation, people \\
\hline People, & Population \\
\hline Creature, & Crowd, \\
\hline Height, stature, body & Belonging to a class \\
\hline & Recognition \\
\hline
\end{tabular}

\section{ConClusion}

This means that the lexical structure of any language in the world does not exist without assimilation words, and languages do not develop without the influence of each other. As words from other languages enter a language, different changes occur in their meaning. In such cases, the meaning may be narrowed or expanded. There are also cases of loss of original and semantic proportions in the sense of the word assimilation from another language. It is also possible that a particular word has a completely different meaning from the meanings it has in its own language, or that it retains the same meaning.

\section{REFERENCES}

1. Iskandarova Sh., Omonov M. Additional compounds in "Boburnoma" that are no longer used in the Uzbek language. - FDU. Messages. Scientific Bulletin. 2019, № 6.pp.-22-25.

2. Mahmudov N. Linguistic research. Tashkent: A classic word. - 2017.

3. Amonov M.U. Linguistic study of isophilic compounds in "Boburnoma": Philol.fanl.fals.doc ..... author's abstract.
Fergana, 2020.

4. An-Naim Arabic-Uzbek dictionary. Tashkent: 2003.

5. Annotated dictionary of the Uzbek language. Volume 1 Tashkent: National Encyclopedia of Uzbekistan. - 2006.

6. Annotated dictionary of the Uzbek language. Volume 2 Tashkent: National Encyclopedia of Uzbekistan. - 2006.

7. Annotated dictionary of the Uzbek language. Volume 3 Tashkent: National Encyclopedia of Uzbekistan. - 2007.

8. Oripova Gulnoza Murodilovna. (2019). The peculiarities of vazn meter in uzbek poetry of the independence period. International Journal of Anglisticum. Literature, Linguisitcs and Interdisciplinary Studies. Volume: 8 /Issue:2/. - Macedonia, 2019. P.33-39.

9. Annotated dictionary of the Uzbek language. Volume 4 Tashkent: National Encyclopedia of Uzbekistan. - 2008.

10. Oripova, G. (2019). Uzbek poetry and the world literature in the years of independence. Scientific Journal of Polonia University, 32(1), 116-120.

11. Annotated dictionary of the Uzbek language. 
CURRENT RESEARCH JOURNAL OF PHILOLOGICAL SCIENCES 2(6): 88-92,

May 2021 DOI: https://doi.org/10.37547/philological-crjps-02-06-18

ISSN 2767-3758

(C)2021 Master Journals

Crossref doi 81 Google

Accepted25thJune, 2021 \& Published 30thJune, 2021

Volume 5 Tashkent: National Encyclopedia of Uzbekistan. - 2008. 